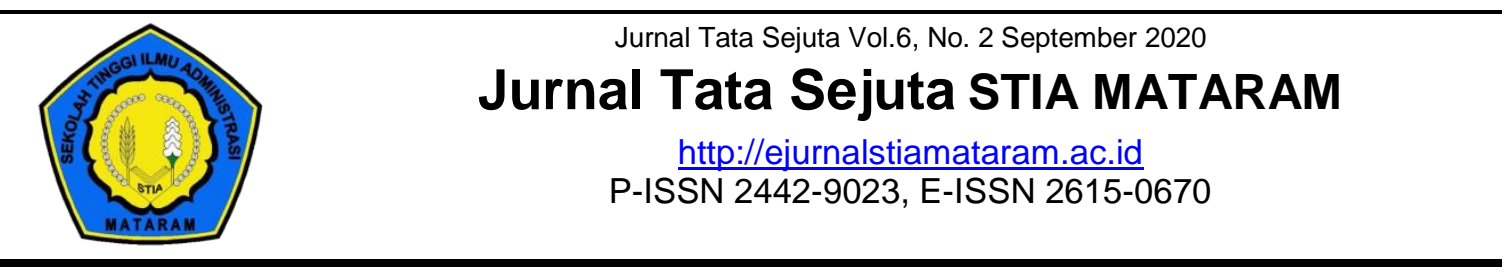

\title{
STRATEGI PENGELOLAAN OBJEK WISATA MANGROVE PANDANSARI SEBAGAI SALAH SATU PENDAPATAN ASLI DAERAH KABUPATEN BREBES
}

\author{
Dwian Hartomi Akta Padma Eldo ${ }^{1}$, Azra Prabowo ${ }^{2}$ \\ 1,2 Prodi Ilmu Pemerintahan, Universitas Pancasakti Tegal
}

\section{Info Artikel}

Sejarah Artikel:

Diterima: 29 Juni 2020

Disetujui: 10 September 2020

Dipublikasikan: 10

September 2020

Kata Kunci:

Strategi pengelolaan,

Pariwisata, Pendapatan

Daerah

\begin{abstract}
Abstrak
Tulisan ini bertujuan untuk melihat bagaimana pemerintah daerah Kabupaten Brebes melakukan pengelolaan tempat wisata Mangrove Pandansari dengan pendekatan Planning, Organizing, Actuating, Controlling, (POAC). Metode Penelitian pada tulisan ini menggunakan pendekatan kualitatif deskriptif. Penulis melakukan wawancara langsung kepada stakeholder seperti, pemerintah daerah Brebes dan juga masyarakat yang mengelola tempat wisata mangrove Pandansari. Tujuannya adalah untuk melihat bagaimana startegi yang dilakukan pemerintah daerah dan juga praktek dilapangan, apakah sudah berjalan sesuai rencana atau belum. Hasil penelitian menunjukkan, bahwa Pemerintah daerah belum maksimal dalam mengoptimalkan Objek Wisata Pandansari sebagai salah satu pendapatan asli daerah kabupaten Brebes. Selain itu Pemerintah daerah dalam hal ini Dinas Pariwisata dan Budaya masih belum efektif dalam melakukan koordinasi dan arahan pengembangan kedepannya dengan pihak pengelola Objek wisata yang dalam hal ini adalah kelompok masyarakat setempat. Maka dari itu beberapa masukan yang bisa diberikan adalah meningkatkan koordinasi dengan pihak pengelola objek wisata serta, membuat draft rancangan pengembangan jangka Panjang dan jangka pendek untuk Objek wisata Mangrove Pandansari.
\end{abstract}

\section{MANGROVE PANDANSARI TOURISM OBJECT MANAGEMENT STRATEGY AS ONE OF THE ORIGINAL INCOME OF BREBES DISTRICT}

\begin{abstract}
This paper aims to see how the local government of Brebes Regency manages the Mangrove Sari tourist sites by using the Planning, Organizing, Actuating, Controlling (POAC). The research method in this paper uses a descriptive qualitative approach. The author conducted interviews directly with stakeholders such as the Brebes local government and also the community that manages the Sari Mangrove tourism site. The aim is to see how the strategies carried out by local governments and also the practice in the field whether it is going according to plan or not. The results showed that the local government has not been maximized in optimizing Pandansari Tourism Objects as one of the original revenue of the Brebes Regency. In addition the local government in this case the Department of Tourism and Culture is still not effective in carrying out coordination and direction for future development with the management of the tourism object in this case the local community group. Therefore, some input that can be given is to improve coordination with
\end{abstract}


the management of attractions and to draft long-term and short-term development plans for Pandansari Mangrove Tourism Objects.

() 2018 Sekolah Tinggi Ilmu Administrasi Mataram

\footnotetext{
Alamat korespondensi:

Dwianhartomieldo@upstegal.ac.id

2Azra.prabowo@gmail.com
}

\section{PENDAHULUAN}

Menurut Undang-Undang Republik Indonesia Nomor 10 tahun 2009 tentang kepariwisataan menyebutkan bahwa, penyelenggaraan kepariwisataan ditujukan untuk meningkatkan pendapatan nasional dalam rangka meningkatkan kesejahteraan dan kemakmuran rakyat, memperluas dan memeratakan kesempatan berusaha dan lapangan kerja, mendorong pembangunan daerah, memperkenalkan dan mendayagunakan obyek dan daya tarik wisata di Indonesia serta memupuk rasa cinta tanah air dan mempererat persahabatan antar bangsa.

Saat ini pariwisata sudah dianggap sebagai salah satu faktor unggulan yang memberikan kontribusi yang cukup besar terhadap pendapatan nasional, Bahkan Mentri Pariwista mengatakan bahwasanya, dalam beberapa tahun terakhir kontribusi sektor pariwisata terhadap perekonomian nasioal cukup besar (Widagdyo, 2015). Hal tersebut menunjukkan bahwa sektor pariwisata memang harus dikelola dengan baik sehingga akan tersu menjadi salah satu pendapatan nasional juga pendapatan daerah. Dengan adanya pariwisata, suatu negara atau lebih khusus lagi Pemerintah Daerah tempat objek wisata itu berada, mendapat pemasukan dari pendapatan setiap wisata (Kurniawan, 2015).

Dengan adanya Undang-Undang Nomor 23 Tahun 2014 tentang Pemerintahan Daerah yang memberikan kewenangan dan penyelenggaran urusan pemerintahan oleh Pemerintah Daerah dan Dewan Perwakilan Rakyat Daerah menurut asas otonomi dan tugas pembantuan dengan prinsip otonomi seluas-luasnya untuk mengelola wilayahnya sendiri, membawa implikasi semakin besarnya tanggung jawab dan tuntutan untuk menggali dan mengembangkan seluruh potensi sumber daya yang dimiliki daerah, dalam rangka menopang pembangunan di daerah.

Pemerintah daerah dituntut untuk menggali pendapatan dari semua potensi yang ada dalam rangka untuk meningkatkan Pendapatan Asli Daerah bagi daerahnya masing-masing. Pendapatan asli daerah merupakan salah satu modal dasar pemerintah daerah dalam mendapatkan dana pembangunan untuk memenuhi belanja daerah. Pendapatan asli daerah merupakan usaha daerah memperkecil 
ketergantungan untuk mendapatkan dana dari pemerintah pusat. Pendapatan Asli Daerah pada dasarnya, komponen utamanya adalah penerimaan yang berasal dari pajak daerah dan retribusi daerah termasuk pengelolaan wisata yang ada di daerah (Riduansyah, 2013).

Semua jenis pendapatan asli daerah tersebut merupakan sumber penerimaan yang murni bagi daerah, artinya pendapatan tersebut berasal dari potensi daerahnya sendiri, sehingga wajar dan selayaknya apabila peran pendapatan asli daerah dalam keungan daerah, merupakan salah satu tolak ukur dalam melaksanakan otonomi daerah yang luas, nyata dan bertanggung jawab.

Pendapatan asli daerah akan membantu daerah dalam mengelola keuangan daerah, agar bisa melakukan pembangunan daerah yang baik. Keuangan daerah dapat diartikan sebagai hak dan kewajiban yang dinilai dengan uang, demikian pula segala sesuatu, baik berupa uang maupun barang yang dapat dijadikan kekayaan daerah, sepanjang belum dikuasai atau dimiliki negara atau daerah yang lebih tinggi atau pihak-pihak lain sesuai dengan ketentuan perundang-undangan yang berlaku (Halim, 2017). Tidak berbeda dengan pendapat (Abdullah, 2015) yang mengatakan Keuangan daerah adalah semua hak dan kewajiban daerah yang dapat dinilai dengan uang dan barang yang dapat dijadikan milik daerah yang berhubungan dengan pelaksanaan hak dan kewajiban tersebut.

Saat ini pembangunan pariwisata perlu mendapatkan prioritas dalam pambangunan nasional. Pembangunan pada umumnya dan pembangunan pariwisata pada khususnya, perlu memperhatikan kondisi daerah serta faktor fisik dan non fisik. Pembangunan adalah sebuah proses dinamis yang didalamnya meliputi berbagai kegiatan yang direncanakan dan terarah dengan melibatkan peran serta masyarakat secara umum sebagai kekuatan pembaharuan untuk menimbulkan perubahan sosial/struktur sosial yang mendasar maupun pertumbuhan ekonomi yang dipercepat namun tetap terkendalikan dalam ruang lingkup keadilan sosial demi kemajuan dan kualitas hidup dan meningkatkan harkat dan martabat manusiawi (Asnudin, 2010).

Kabupaten Brebes merupakan salah satu Kabupaten yang dalam wilayah Provinsi Jawa Tengah. Kabupaten Brebes dengan posisi wilayah yang berada pada Pantai Utara Pulau Jawa juga memiliki Ekowisata dalam bentuk hutan mangrove. Dari beragam obyek wisata di Brebes, potensi yang menjadi unggulan teratas untuk memenuhi Pendapatan Asli Daerah adalah Hutan Mangrove Pandansari, Brebes. Hal demikian menunjukkan, bahwa obyek wisata yang lain terkesan belum memberikan kontribusi yang berarti bagi pendapatan asli daerah pemerintah kabupaten Brebes. 
Maka dari itu pemerintah daerah melalui Dinas Kebudayaan dan Pariwisata mengambil kebijakan untuk melakukan pembangunan di sektor wisata yang diharapkan mampu memberikan kontribusi yang cukup berarti bagi pembangunan daerah, sehingga tolak ukur keberhasilan dari usaha tersebut tidak hanya terbatas pada kesuksesan rencana dan pelaksanaan program pembangunan pariwisata, akan tetapi seberapa besar sektor pariwisata mampu memberikan kontribusi bagi pendapatan daerah.

Pada dasarnya objek wisata dikelompokkan menjadi 3 jenis diantaranya; (1) Objek Wisata Alam seperti Laut, pantai, hutan mangrove, gunung, dll; (2) Objek Wisata Budaya diantaranya; tari-tari (tradisional), musik (tradisional), pakaian adat, dll; (3) Objek Wisata Buatan diantaranya; sarana dan fasilitas olahraga, taman rekreasi, taman nasional (Sulistyo, 2017).

Dinas Kebuyadaan dan Pariwisata wilayah Kabupaten Brebes, Jawa Tengah memiliki tugas untuk melaksanakan urusan pemerintahan Kabupaten Brebes dalam bidang budaya dan pariwisata berdasarkan asas otonomi daerahnya. Mulalui Dinas pariwisata dan kebudayaan atau yang disingkan Disparbud ini, berbagai urusan pemerintah daerah terkait bidang pariwisata dan kebudayaan dilakukan.

Untuk menjadikan Objek Wisata Hutan Mangrove Pandansari diminati untuk dikunjugi wisatawan, membutuhkan pengelolaan yang baik serta Kerjasama antara masyarakat dan pemerintah, sehingga mendapatkan hasil yang maksimal. Manajemen merupan suatu proses yang membedakan atas perencanaan, pengorganisasian, pelaksanaan, dan pengawasan, dengan memanfaatkan baik ilmu maupun seni, agar dapat mencapai tujuan yang telah ditetapkan sebelumnya (Larasati, 2018).

Pada dasarnya pengelolaan pariwisata adalah suatu proses yang berkeseimbangan untuk melakukan matching and adjustment yang terus menerus antara sisi supply dan demand kepariwisataan yang tersedia untuk mencapai misi yang telah di tentukan (Widagdyo, 2015). Pengelolaan pariwisata memang harus dikelola dengan serius jika ingin mendapatkan hasil yang maksimal terutama perihal pendapatan suatu daerah.

Obyek Wisata Mangrove Pandansari merupakan satu-satunya obyek hutan mangrove yang ada di Kabupaten Brebes, terletak di dukuh Pandansari, Desa Kaliwlingi, Kecamatan Brebes. Obyek wisata ini memiliki luas sekitar 250 ha dan sedang di kembangkan oleh pemerintah kabupaten Brebes yang di bangun pada tahun 2016, untuk saat ini keberadaannya di kelola oleh Dinas Kebudayaan dan Pariwisata Kabupaten Brebes. Selain atraksi wisata, obyek wisata ini juga di lengkapi dengan 
berbagai sarana dan fisilitas wisata, diantaranya yaitu, mushola, toilet, pedagang, kantor pengelola dan lain sebagainya.

Pengelolaan objek wisata tidak boleh mengabaikan alam disekitarnya, sehingga harus merawat dan menjaganya. Karena dalam tahap pengembangan Kawasan wisata juga harus berorientasi pada pelestarian lingkungan sekitar (Darmawan \& Fadjarajani, 2016).

Dari berbagai potensi wisata daerah, obyek wisata mangrove Pandansari menunjukan bahwa obyek wisata ini memberikan kontribusi yang cukup besar untuk pariwisata di Kabupaten Brebes. Didukung dengan jumlah wisatawan (pengunjung) yang cukup tinggi. Untuk lebih jelasnya bisa kita lihat pada table 1 dibawah ini :

Tabel 1.

Jumlah Pengunjung Objek Wisata Hutan Mangrove Pandansari Tahun 2019

\begin{tabular}{|l|c|}
\hline \multicolumn{1}{|c|}{ Bulan } & Obyek Wisata \\
\cline { 2 - 2 } & Hutan Mangrove Pandansari (jiwa) \\
\hline Januari & 17.299 \\
\hline Februari & 16.428 \\
\hline Maret & 10.836 \\
\hline April & 12.964 \\
\hline Mei & 21.468 \\
\hline Jumlah & $\mathbf{7 8 . 9 9 5}$ \\
\hline
\end{tabular}

Terlihat data pengunjung di dalam tabel diatas, wisatawan cukup tertarik dengan ekowisata Hutan Mangrove Pandansari sebagai salah satu pilihan objek wisata yang ada di Kabupaten Brebes. Oleh karena itu Pemerintah Kabupaten Brebes melalui Dinas Kebudayaan dan Pariwisata dalam mengelola pariwisata harus memiliki peranan penting dalam bentuk strategi-strategi seperti memanfaatkan lingkungan secara lestari, melibatkan masyarakat secara aktif, dan menyediakan sarana pendidikan yang memadai, kemudian disediakan media pembelajaran dan rekreasi, untuk meminimalkan dampak negatif terhadap lingkungan, dan memberikan sumbangan positif terhadap pembangunan otonomi daerah.

Pengelolaan pariwisata yang baik akan berdapampak terhadap sumbagan untuk pendapatan asli daerah, dengan demikian jumlah pengunjung atau wisatawan yang datang pada daerah pariwista akan linearitas terhadap pendapat daerah sebagaimana yang terlihat pada tabel dibawah ini : 
Tabel 2.

Jumlah Pengunjung dan Pendapatan Objek Wisata Hutan Mangrove Pandansari

\begin{tabular}{|l|c|c|c|}
\hline Tahun & $\begin{array}{c}\text { Jumlah } \\
\text { Pengunjung } \\
\text { (org) }\end{array}$ & $\begin{array}{c}\text { Jumlah } \\
\text { Pendapatan } \\
\text { Penjualan } \\
\text { (Rp) }\end{array}$ & $\begin{array}{c}\text { Jumlah } \\
\text { Pendapatan } \\
\text { lain-lain } \\
\text { (Rp) }\end{array}$ \\
\hline 2016 & 21.334 & 105.025 .000 & 20.740 .000 \\
\hline 2017 & 64.807 & 186.960 .000 & 120.490 .000 \\
\hline 2018 & 80.864 & 228.010 .000 & 175.127 .000 \\
\hline
\end{tabular}

Potensi pariwisata Hutan Mangrove Pandansari Kabupaten Brebes perlu di kembangkan dan di bina secara terarah, terpadu dan berkelanjutan agar dapat meningkatkan kesejahteraan dan kemakmuran masyarakat, memperluas kesempatan kerja dan usaha dan pemerataan pendapatan, pada akhirnya mampu menunjang pembangunan daerah Kabupaten Brebes. Perkembangan pariwisata Kabupaten Brebes dari tahun ke tahun belum menampakkan keberhasilannya dalam pengelolaan obyek-obyek wisata didaerah tersebut. Maka dari itu ada hal yang menarik untuk dilihat perihal bagaimana starategi yang dilakukan oleh Pemerintah kabupaten Brebes dalam mengelola Hutan Mangrove Pandansari yang menjadi salah satu pendapatan asli daerah.

\section{METODE PENELITIAN}

Penelitian ini menggunakan metode dalam pendekatan deskriptif kualitatif. Tujuannya adalah untuk menjelaskan keadaan atau menggambarkan subyek atau obyek sasaran yang harus di teliti dan diambil datanya sehingga membantu dalam penelitian ini. (Moleong, 2013).

Penelitian deskriptif bertujuan untuk mengetahui nilai variable mandiri, baik satu variable atau lebih tanpa membuat perbandingan atau menghubungkan antara variable yang satu dengan variable yang lainnya (Sugiyono, 2016). Maka dari itu metode ini dianggap cukup mampu menjawab rumusan masalah yang ada penelitian ini. Teknik pengumpulan data yang digunakan adalah dengan cara wawancara, Observasi dan dokumentasi. Hal tersebut dianggap cukup untuk mampu menjelaskan tentang bagaiamana stakeholder berperan dalam mengelola objek wisata hutan mangrove Pandansari yang ada di Kabupaten brebes. Data hasil wawancara dari beberapa informan dan observasi langsung dengan didukung analisis dari dokumen yang tersedia sehingga mampu mendapatkan informasi yang cukup untuk dianalisis oleh penulis. Sumber informasi dalam penelitian ini adalah pelaku yang terlibat langsung dengan permasalahan penelitian. Diantaranya adalah dinas pariwisata dan budaya 
kabupaten Brebes yang bertanggungjawab untuk mengelola dan mengembangkan seluruh wisata yang ada. Selain itu informasi juga didapatkan dari kelompok masyarakat yang mengelola ekowisata hutang mangrove pandansari. Proses pemilihan informan tidak mengacu pada banyak jumlah informasi yang akan dipilih, namun lebih kepada kedalam informasi yang diperoleh peneliti. Jika digambarkan operasional peenlitian secara ringkas dapat dilihat pada gambar dibawah ini;

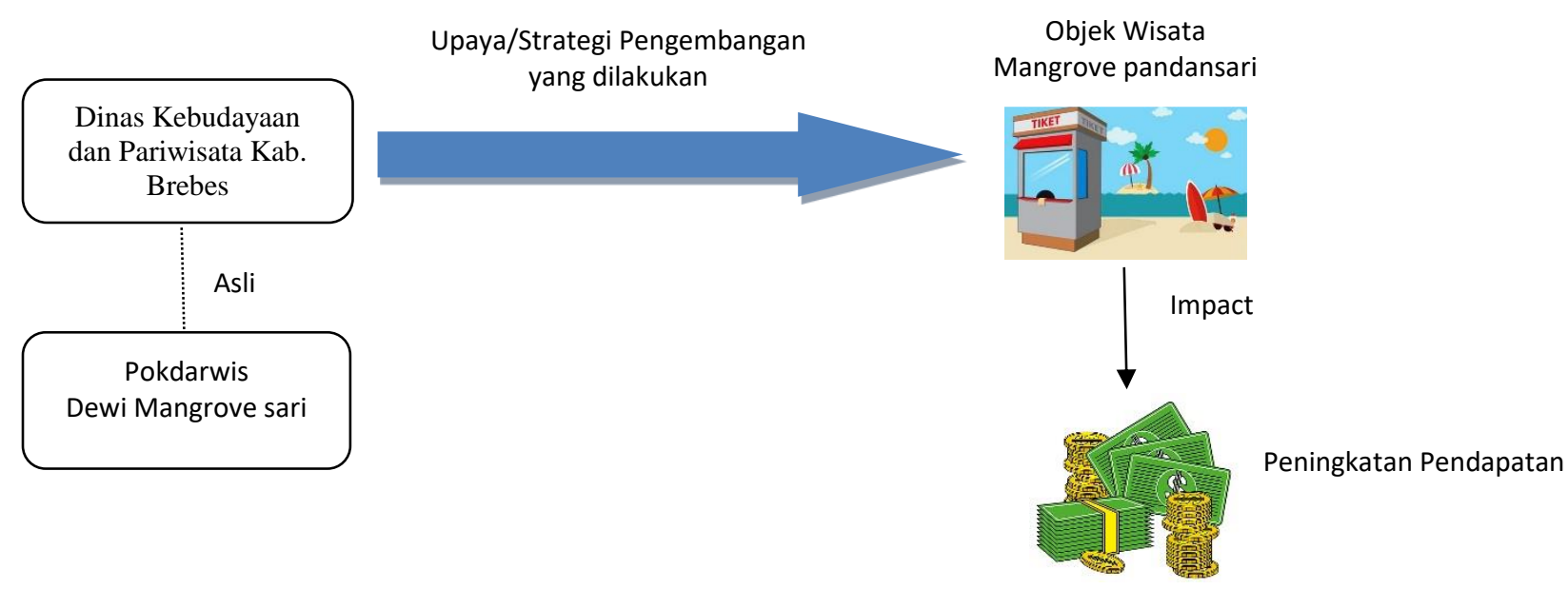

\section{HASIL DAN PEMBAHASAN}

Berdasarkan hasil penelitian, berdirinya obyek wisata mangrove pandansari adalah berawal dari usaha masyarakat mencegah abrasi dengan cara menanam tanaman mangrove. Melihat berbagai kesempatan dan potensi serta daya tarik masyarakat tentang edukasi tanaman mangrove. Maka masyarakat sekitar Dukuh Pandansari, Desa Kaliwlingi menjadikan hutan mangrove sebagai obyek wisata mangrove. Obyek wisata mangrove ini sudah berkembang sejak tahun 2016, dan didukung oleh dinas kebudayaan dan pariwisata kabupaten Brebes obyek wisata mangrove sekarang ini mulai berkembang dan dikenal oleh masyarakat luas.

Di tahun yang ke- 3 (Tahun 2019) tentunya masih banyak kekurangan mulai dari penganggaran sampai pada peranan yang dilakukan oleh dinas kebudayaan dan Pariwisata. Kekurangannya sangat terlihat dari lemahnya aturan hukum yang diberlakukan untuk obyek wisata mangrove pandansari, yaitu aturan tentang PAD. Sangat terlihat peran dinas kurang maksimal bahkan kurang tegas menindak kekurangan tersebut. Serta peranan dari Dinas Kebudayaan dan Pariwisata pun tidak ada desakkan agar segera tercipta aturan tersebut. Mengingat obyek wisata mangrove Pandansari adalah obyek wisata yang sangat potensial. Melihat grafik pengunjung yang semakin meningkat di setiap tahunnya. Jika ini tidak di manfaat sebagai sumber 
pendapatan asli daerah (PAD) kabupaten Brebes, maka hal ini sangat disayangkan. Pemasukan yang didapat sangatlah besar tentunya ini akan sangat berdampak pada pembangunan kabupaten Brebes jika pendapatan ini dikelola dengan baik.

Selain itu masyarakat dalam hal ini adalah pengelola, masih sangat tegas tidak ingin di kelola oleh pemerintah. Karena kurangnya kepercayaan masyarakat terhadap pemerintah dalam hal ini kepada Dinas Kebudayaan dan Pariwisata Kabupaten Brebes. Banyak obyek wisata di kabupaten Brebes yang dikelola oleh pemerintah mengalami kegagalan dalam segi pengelolaan. Mulai dari fasilitas banyak rusak sampai pada kebersihan yang masih dianggap kumuh, hal itu akan berdampak terhadap kenyamanan pengunjung. Ketidakpercayaan masyarakat terhadap peran dan pengololaan oleh dinas kebudayaan dan pariwisata kabupaten Brebes tersebut, membuat pokdarwis obyek wisata mangrove menolak jika obyek wisata mangrove pandansari di kelola oleh pemerintah.

Tentunya ini akan sangat merugikan pemerintah kabupaten Brebes. Mengingat obyek wisata mangrove pandansari adalah obyek wisata yang sangat potensial. Kurang maksimalnya peranan yang dilakukan oleh dinas kebudayaan dan Pariwisata terhadap pengelolaan obyek wisata di kabupaten Brebes, membuat masyarakat kelompok sadar wisata (POKDARWIS) obyek wisata mangrove pandansari tidak percaya jika akan di kelola oleh dinas kebudayaan dan pariwisata.

\section{1) Planning (Perencanaan)}

Fungsi Planning (Perencanaan) menjadi hal yang penting dalam melakukan sesuatu hal, baik kebijakan atau dalam suatu strategi. Berdasarkan hasil penelitian yang dilakukan langsung kepada Dinas Kebudayaan dan pariwisata Kabupaten Brebes selaku Pembina utama, ditemukan bahwa tidak memiliki draft perencanaan pengembangan Tahunan, yang berisi data perencanaan jangka pendek, jangka menengah dan juga jangka Panjang.

Draft perencanaan pengembangan sejatinya harus dimiliki oleh setiap Instansi dalam melakukan pengelolaan tempat wisata. Tempat wisata menjadi suatu tempat yang dapat meningkatkan pendapatan asli daerah (PAD), maka dari itu draft perencanaan sangat dibutuhkan agar pengembangan wisata mangrove pandansari dapat terukur dan bisa dievaluasi dengan baik dan objektif dari berbagai pihak manapun.

Temuan ini menunjukkan bahwa sangat sulit mengukur sejauh mana capaian yang telah dilakukan oleh dinas Kebudayaan dan Pariwisata Kabupaten Brebes dalam 
pengembangan objek Wisata mangrove pandansari. Hal itu akan memiliki dampak kepada Pokdarwis yang menjadi partner pemerintah dalam pengelolaan tempat pariwisata. Posisi Pokdarwis sebagai pelaksana lapangan akan kebingungan, karena tidak adanya arah pengembangan yang hendak dilakukan oleh pemda perihal pengembangan wisata mangrove pandansari.

Salah satu penghambat dalam pengembangan pariwisata hutan mangrove pandansari, dikarenakan Sumber Daya Manusia yang dimiliki oleh Dinas Kebudayaan dan Pariwisata sangat minim pengetahuannya terhadap fungsi perencanaan. Pemamahan yang dimiliki hanya sebatas bagaimana obyek wisata mangrove ini bisa berkembang dan dikunjungi banyak wisatawan setiap harinya. Pemahaman seperti itu sebenarnya memiliki dampak kurang bagus terhadap pengembangan tempat wisata, karena arah pengembangan wisata tidak jelas arahnya. Padahal wisata tersebut menjadi salah satu "Andalan" dalam pendapatan daerah.

Berdasarkan temuan yang sudah dipaparkan, menjadi tugas yang utama yang harus dilakukan oleh Dinas Kebudayaan dan Pariwisata Kabupaten Brebes untuk mampu mengembangkan SDM yang dimiliki agar mampu menjawab kebutuhan arah perencanaan pengembangan kedepannya. Hal tersebut menjadi penting juga oleh pengelola Pokdarwis agar terjadinya sinergisitas dalam pengembangan objek wisata mangrove pandansari. Karena akan berdampak terhadap jumlah kunjungan wisatawan yang akan datang.

Draft perencanaan menjadi hal utama dalam perbaikan manajemen pengelolaan dalam strategi pengembangan objek wisata mangrove pandansari. Agar nantinya pengembangan yang dilakukan terukur dengan baik dan bisa dievaluasi untuk keberlanjutannya. Selain itu dapat meningkatkan sepemahaman dengan pengelola objek wisata tersebut agar bisa berjalan dengan baik.

\section{2) Organizing (Pengorganisaian)}

Pengorganisasian dalam pemahaman sederhananya ialah, siapa, melakukan apa. Berdasarkan hasil temuan lainnya ternyata peranan pengorganisasian yang dilakukan oleh dinas kebudayaan dan pariwisata kabupaten Brebes belum Maksimal. Dinas kebudayaan dan pariwisata selaku Pembina utama, tidak mengatahui bahwa fakta yang terjadi di lapangan yaitu adanya penarikan kas PAD yang dimasukkan kedalam harga tiket. Dalam hal ini dibebankan kepada pengunjung yang akan berkunjung ke obyek wisata mangrove. Hal tersebut tidak dibenarkan adanya, karena semakin membebani pengunjung dengan harga tiket yang cukup mahal. 
Pada kenyataan penarikan kas PAD tidak disetorkan secara langsung kepada pihak pemerintah daerah. Hal tersebut menunjukkan bahwa tidak adanya koordinasi baik antara pemerintah daerah dan pengelola dari segi pengorganisasian, karena hilangnya hak dan kewajiban yang sudah diatur dalam peraturan daerah. Hak pengelola yaitu untuk mengelola, sedangkan kewajiban pengelola yaitu menyetorkan PAD kepada pemerintah daerah, selaku pembina utama Dinas kebudayaan dan pariwisata kabupaten Brebes dan pengelola tidak menjalankan fungsi pengorganisasian dengan baik, yaitu siapa, melakukan apa.

Temuan lainnya menunjukkan pada tahap pengorganisasian banyak terjadi ketidakpahaman tentang tugas pokok dan fungsi. Hal tersebut berdampak pada koordinasi yang buruk antara pemerintah daerah dan pihak pengelola. Dinas kebudayaan dan pariwisata kabupaten Brebes selaku Pembina utama sejatinya harus memberikan pemahaman kepada pengelola agar setiap permasalahan bisa diatasi dan diberikan solusi terbaik. Menjalin komunikasi dengan baik agar tidak terjadi kesalahan pahaman antar hak dan kewajiban yang harus dilaksanakan baik pengelola ataupun dari pihak pemerintah daerah. Harapannya agar pengembangan dan pengelolaan obyek wisata mangrove pandansari bisa berkembang dengan baik serta dapat menjadi sektor pariwisata unggulan di Kabupaten Brebes.

\section{3) Actuating (Pelaksanaan)}

Pelaksanaan program pengembangan tentunya tidak akan bisa dilakukan secara sepihak oleh dinas kebudayaan dan pariwisata selaku Pembina utama ataupun dilakukan sepihak pula oleh pengelola yaitu POKDARWIS (Kelompok Sadar Wisata). Tentunya pelaksanaan program ini harus melibatkan banyak instrument, diantaranya instrument masyarakat dan juga pemerintah daerah dalam hal ini diwakilkan oleh dinas kebudayaan dan pariwisata kabupaten Brebes.

Pelaksanaan program tentunya juga harus mempertimbangkan aspek aspek perekonomian dan sosial. Dari aspek perekenomian pemerintah harus tegas dalam merancang aturan dengan tidak adanya investor tunggal dan juga tidak adanya pasar modern (Indomaret dan Alfamaret) yang masuk kedalam obyek wisata mangrove pandansari. Jika pasar modern ini masuk kedalam obyek wisata mangrove pandansari tentunya akan merusak perekonomian masyarakat. Karena objek wisata mangrove pandansari saat ini menjadi salah satu sumber perekonomian warga sekitar. Karena dalam aspek sosial, pemerintah dituntut harus mampu mensejahterakan masyarakat dengan memberikan peluang untuk mengembangkan bisnis dagang di dalam obyek 
wisata mangrove pandansari. Keterlibatan masyarakat dalam pengelolaan obyek wisata mangrove pandansari ini sangat membantu meningkatkan perekonomian masyarakat.

Melalui dinas kebudayaan dan pariwisata, masyarakat berharap mampu mencegah masuknya investor-investor yang datang dari untuk tidak membuka toko modern (Indomaret dan Alfamaret) yang akan merusak ekosistem perekonomian masyarakat. Dengan membuat aturan-aturan dan tata tertib yang tegas dinas kebudayaan dan pariwisata kabupaten Brebes harapannya menjadi garda terdepan melawan ketika harus ada investor dari luar ingin masuk ke lokasi obyek wisata mangrove pandansari. Pelaksanaan program tentunya juga harus diimbangi pula dengan aspek-aspek sosial. Tentunya ketika pengembangan obyek wisata mangrove pandansari mengalami pembangunan harus melihat perkembangan aspek sosial masyarakatnya. Tentunya masyarkat dalam hal ini harus memiliki kapasitas untuk turut serta dalam pengembangan obyek wisata mangrove pandansari.

Temuan menarik lainnya adalah perihal kendalanya yang terjadi di masyarakat, tidak semua masyarakat sadar adanya pengembangan obyek wisata mangrove pandansari. Oleh karena itu tidak sedikit pula masyarakat yang acuh terhadap pengembangan obyek wisata pandansari ini, terutama masyarakat sekitar. Kiranya dinas kebudayaan dan pariwisata selaku Pembina utama harus melakukan sosialisasi pemahaman agar masyakarat merasa memiliki obyek wisata pandansaari ini seacar bersam, sehingga masyarkat akan bersama-sama mengembangkan dan menjaganya agar menjadi obyek wisata yang unggulan di kabupaten Brebes. Selain itu juga pelaksanaan pembangunan dan pengembangan obyek wisata mangrove pandansari ini akan berjalan dengan lancar karena didukung oleh berbagai-bagai instrument pendukung yaitu pemerintah daerah yaitu melalui dinas kebudayaan dan pariwisata kabupaten brebes, pengelola dan tentunya masyarakat sekitar obyek wisata mangrove pandansari.

\section{4) Controlling (Pengawasan)}

Berdasarkan hasil temuan, Dinas Kebudayaan dan Pariwisata tidak melakukan pengawasan sesuai aturan yang berlaku. Seharusnya ada pengawasan yang berkala dilakukan oleh Pemda untuk melihat bagaimana pengembangan yang terjadi di objek wisata mangrove pandansari. Namun pada kenyataanya pihak dinas pariwisata hanya melakukan pengawasan tidak dan tidak dengan jelas, pihak dinas kebudayaan dan pariwisata hanya melakukan pengawasan dalam rentan waktu 3 (tiga) bulan sekali. 
Sedangkan pelaporan yang harus dilakukan oleh pengelola adalah setiap bulan, hal tersebut menunjukkan masih minimnya komitmen perihal pengawasan yang dilakukan oleh pemerintah daerah untuk objek wisata pandansari kabupaten Brebes.

Fungsi peranan yang terakhir yaitu controlling tentunya dinas kebudayaan dan pariwisata kabupaten Brebes harus melakukan monev (Monitoring and evaluation) setiap bulan terhadap pengelola. Ada temuan yang menarik perihal kendala yang terjadi dari dinas kebudayaan dan pariwisata, yaitu selalu memundurkan waktu monitoring, sehingga waktu monitoring dilaksanakan setiap 6 bulan sekali. Dengan alasan kesibukkan harus mengontrol obyek pariwaisata yang lainnya yang ada di kabupaten Brebes. Hal tersebut sebenarnya bisa diatasi dengan baik dengan jumlah SDM yang dimiliki dan strategi yag baik kedepannya.

Kepala Dinas Kebudayaan dan Pariwisata menjelaskan bahwa kurangnya sumber daya manusia menjadi hambatan dalam pengembangan pariwisata hal ini terlihat dalam susunan struktural yang ada di Dinas Kebudayaan dan Pariwisata Kabupaten Brebes. Dinas Kebudayaan dan Pariwisata Kabupaten Brebes memiliki sumber daya manusia aparatur sebanyak 34 (tiga puluh empat) orang yang terdiri dari 17 (tujuh belas) orang Pejabat Struktural, 16 (enam belas) orang non struktural.

Berdasarkan analisis beban kerja dibandingkan banyaknya SDM yang ada masih belum mencukupi kebutuhan, sedangkan dari segi pendidikan jumlah Sarjana S2 sebanyak 2 (dua) orang, S1 17 (tujuh belas) orang, Diploma III 9 (sembilan) orang, SLTA 6 (enam) orang.

Selain faktor sumbe rdaya manusia, faktor lain yang menjadi penghambat adalah kurang koordinasinya Dinas Kebudayaan dan Pariwisata dengan pihak -pihak terkait dalam lintas sektoral yang berhubungan dengan pengembangan Obyek Wisata Mangrove Pandansari seperti Dinas Pekerja Umum, Dinas Lingkungan Hidup dan lain sebagainya .Dalam hal ini Dinas Kebudayaan dan Pariwisata seharusnya bisa menjaga koordinasi dengan pihak -pihak terkait agar pengembangan obyek wisata Mangrove Pandansari dapat berjalan dengan baik. Hal ini menjadi hambatan dalam mengembangkan obyek wisata Mangrove Pandansari yang ada di Kabupaten Brebes. Selain itu belum terjalinnya kerjasama dengan para pelaku-pelaku usaha hingga penanganan di sektor pariwisata belum maksimal menjadi hambatan tersendiri dalam pengelolaan wisata hutan mangrove Pandasari Brebes. Hambatan lainnya adalah terlambatnya perencanaan pembangunan fisik, karena kurangnya koordinasi lintas sektoral mengakibatkan pembangunan fisik menjadi terlambat untuk 
dilaksanakan. Diketahui Kabupaten Brebes lima tahun terakhir fokus pada pembangunan infrastruktur penunjang kegiatan ekonomi yang bersifat fisik berupa bangunan areal industrial dan perkantoran, sehingga perencanaan pembangunan penunjang pariwisata terhambat.

\section{PENUTUP}

Kesimpulan dan Saran penulis dapat menyimpulkan beberapa poin utama, yang menjadi acuan dari hasil penelitian yang dilakukan pada bidang obyek wisata mangrove pandansari adalah Strategi yang dilakukan oleh pemerintah daerah kabupaten Brebes melalui dinas kebudayaan dan pariwisata kabupaten Brebes dengan melakukan fungsi manajemen dengan menerapkan Planning, Organizing, Actuating, Controlling (POAC). Dilihat dari fungsi Planning (Perencanaan) ternyata Dinas Kebudayaan dan Pariwisata belum memiliki draft perencanaan pengembangan objek wisata Mangrove Pandansari, baik jangka pendek, menengah ataupun Jangka Panjang. Hal tersebut menyulitkan untuk melihat sejauh mana perkembangan objek wisata tersebut dan capaian yang telah dilakukan. Selanjutnya dilihat dari fungsi organizining (Pengorganisasian) ternyata antar Dinas Kebudayaan dan Pariwisata dan pihak pokdarwis selaku peneglola masih ada ketidaksepemahaman dalam penarikan iuaran dan juga hak dan kewajiban yang diperoleh. Hal tersebut menunjukkan masih belum maksimalnya komunikasi antara pemerintah daerah dan pihak pengelola.

Untuk fungsi actuating (pelaksanaan) masih minimnya komunikasi dan kesepemahaman antara Dinas Kebudayaan dan Pariwisata dengan Pokdarwis dalam mengelola serta pengembangan Objek wisata mangrove pandansari. Dan terakhir fungsi controlling (pengawasan) yang dilakukan Dinas Kebudayaan dan Pariwisata masih belum maksimal dan tidak berkala dengan baik, sehingga ditemukan kesalahan perihal setoran untuk PAD yang dibebankan kepada wisatawan.

Setiap peranan yang dilakukan oleh Dinas kebudayaan dan Pariwisata Kabuapten Brebes belum maksimal. Tentunya pemerintah daerah, melalui dinas kebudayaan dan pariwisata kabupaten Brebes harus melakukan evalusi terhadap fungsi peranan yang dilaksanakan oleh Dinas Kebudayaan dan Pariwisata Kabupaten Brebes. Supaya Objek wisata mangrove pandansari bisa berkembang dengan baik dan membuat daya Tarik tersendiri untuk wisatawan yang berkunjung ke tempat objek wisata tersebut.

Masih belum maksimalnya strategi pengelolaan yang dilakukan oleh pemerintah daerah, menunjukan bahwa masih belum maksimalnya pemasukan untuk PAD pada sektor pariwisata di Kabupaten Brebes. Diharapkan fungsi POAC benar- 
benar bisa dijalankan secara maksimal sehingga strategi pengelolaan yang dilakukan untuk objek wisata mangrove pandansari bisa berjalan dengan baik dan juga mampu menambah pemasukan daerah menjadi maksimal tentunya.

\section{DAFTAR PUSTAKA}

Abdullah, R. (2015). Pelaksanaan Otonomi Luas Dengan Kepala Daerah Secara Langsung. Jakarta: Raja Grafindo.

Asnudin, A. (2010). PENDEKATAN PARTISIPATIF DALAM PEMBANGUNAN PROYEK INFRASTRUKTUR PERDESAAN DI INDONESIA. SMARTEK, 182190.

Darmawan, D., \& Fadjarajani, S. (2016). HUBUNGAN PENGETAHUAN DAN SIKAP PELESTARIAN LINGKUNGAN DENGANPERILAKU WISATAWAN DALAM MENJAGA KEBERSIHAN LINGKUNGAN. Jurnal Geografi, 37-49.

Halim. (2017). Auditing (Dasar-dasar Audit Laporan Keuangan). Yogyakarta: Unit Penerbit dan Percetakan STIM YKPN.

Kurniawan, W. (2015). DAMPAK SOSIAL EKONOMI PEMBANGUNAN PARIWISATA UMBUL SIDOMUKTI KECAMATAN BANDUNGAN KABUPATEN SEMARANG. Economics Development Analysis Journal , 443-451.

Larasati, S. (2018). MANAJEMEN SUMBERDAYA MANUSIA. Yogyakarta: Deepublish. Moleong, L. J. (2013). METODE PENELITIAN KUALITATIF ; EDISI REVISI. Bandung: Remaja Rosdakarya.

Riduansyah, M. (2013). KONTRIBUSI PAJAK DAERAH DAN RETRIBUSI DAERAH TERHADAP PENDAPATAN ASLI DAERAH DAN ANGGARAN PENDAPATAN BELANJA DAERAH GUNA MENDUKUNG PELAKSANAAN OTONOMI DAERAH (STUDI KASUS PEMERINTAH DAERAH KOTA BOGOR). Makara, Sosial Humaniora, 49-57.

Sugiyono. (2016). METODE PENELITIAN KUANTITATIF, KUALITATIF DAN R\&D. Bandung: Alfabet.

Sulistyo, A. (2017). ANALISIS SWOT 8-K PADA OBJEK WISATA REKREASI DAN HIBURAN KELUARGA KID'S FUN YOGYAKARTA. Kepariwisataan : Jurnal IImiah, 1-10.

Widagdyo, K. G. (2015). ANALISIS PASAR PARIWISATA HALAL INDONESIA. The Journal of Tauhidinomics, 73-80. 